\section{THE COMPUTATIONAI PROBLEM OF USING OWA OPERATORS}

\author{
Visuenor CUTELLO \\ Sex. of Mothemalion \\ linsiversity of ciategcio \\ Cotonia. tidy
}

Javjer MONTERe

Brp. of Statistics and D.R

Conpolatenar bisidessity

Nadrids Spais

\title{
Abovear
}

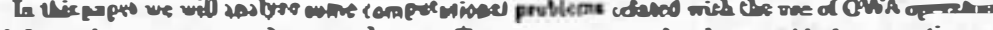

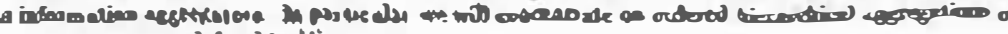
OPRA operwars is defibed in If

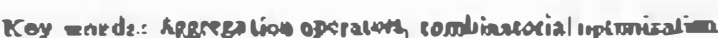

\section{Introduction and preliminaries}

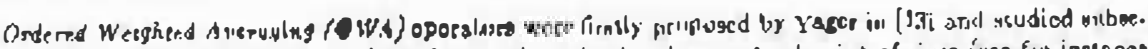

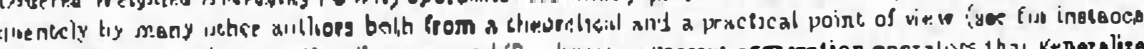

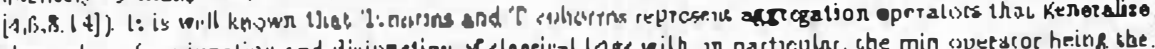

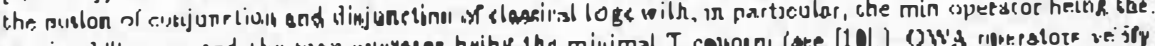

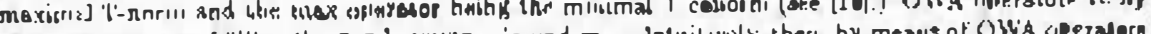

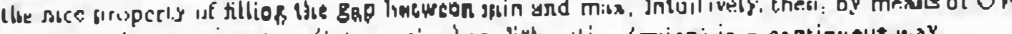
W

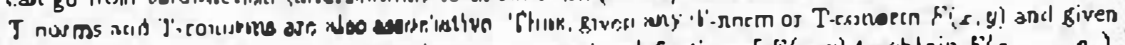

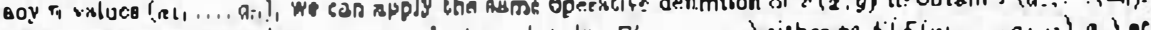

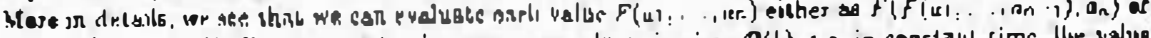

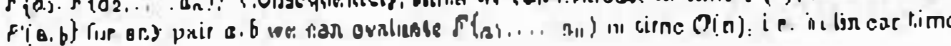

\subsection{OW'A operaters}

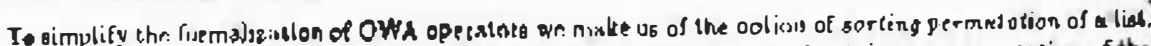

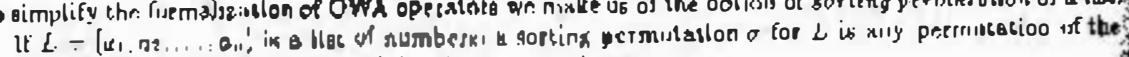

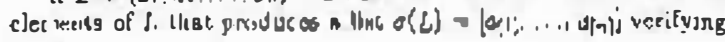

$$
\text { ‘,il } 2 \text { ov", }
$$

\section{[ns s.ll $i \leq$;}

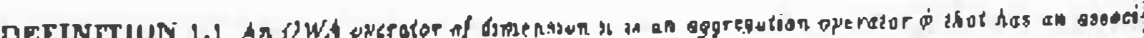

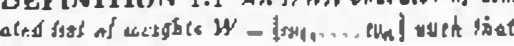

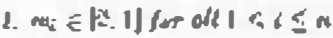

2. $\sum_{1}^{0}, 11$

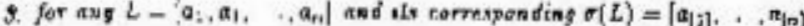

$$
\phi(1 .)=\sum_{i=1}^{n} \omega_{i} \otimes(1)
$$

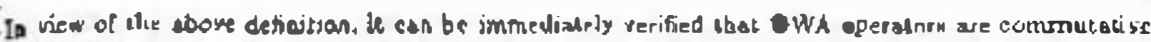

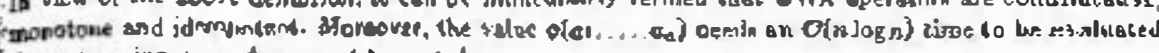
pioce the on imp $\pi t$ and

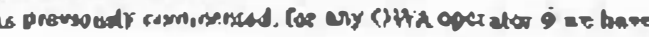

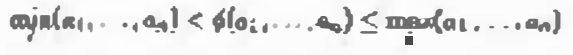

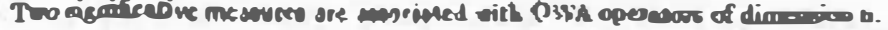

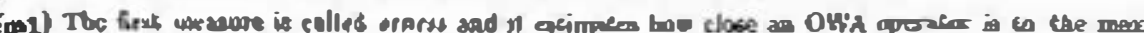

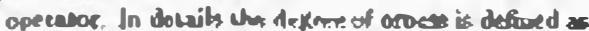

As uhown in [13,

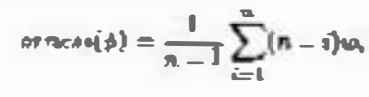

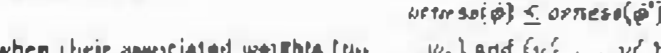

$$
\sum_{i=1}^{\infty} y_{i}<\sum_{i=1}^{\infty} w_{j}^{\prime} \nabla_{i}=1, \ldots n
$$

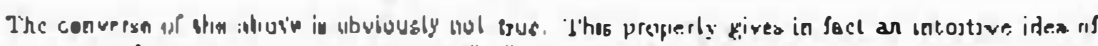

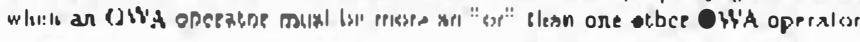

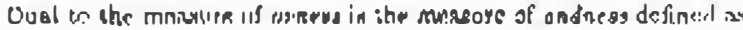

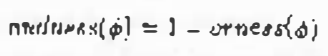

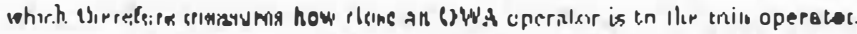

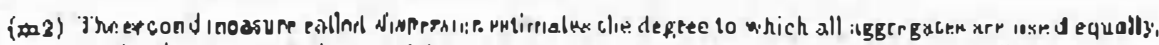

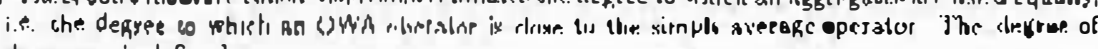
dispstran! it dnfiurld a

$$
\text { Sizepp(u) }=-\sum_{i=1}^{n} u_{i} \ln x_{i}
$$

\section{Ordcred himsurchles of OWA operators}

\subsection{Hierarehical Gugregatlons}

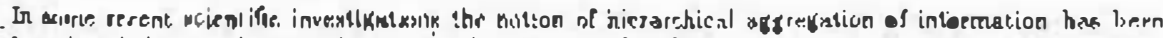

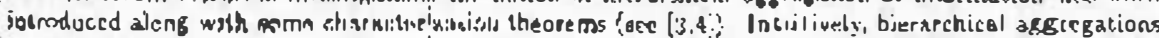

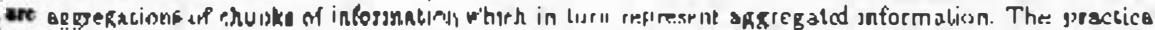

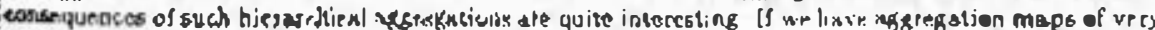

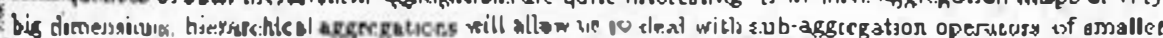

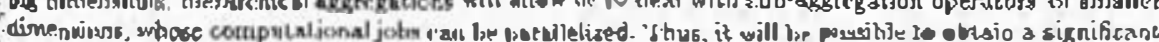

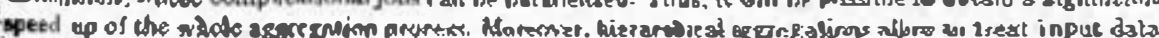

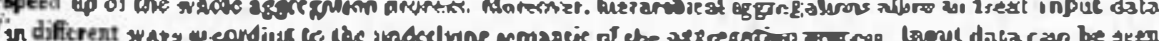

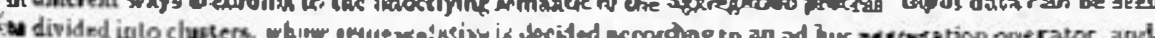




\subsection{Hieracehical segregations of OWA opecators}

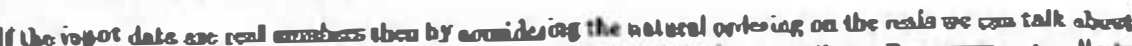

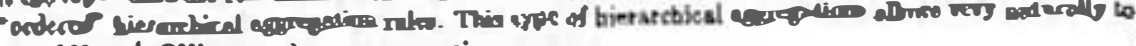

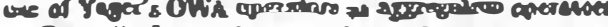

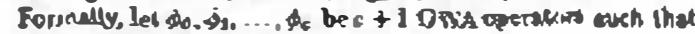

- Do has dirnoneioa

- $\phi_{i}$ bas dimenaios $\boldsymbol{h}_{i}$ for asiy $i=1,3, \ldots, c$

- $\sum_{i=1}^{\infty} A_{0}=n$

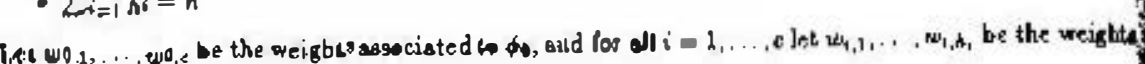
aesocipted to $\phi_{i}$

DEFIN ITION 2.1 The ordored hieratijeal cocopurition of $\phi_{0 .} \phi_{1}, \ldots, \phi .18$ defined by

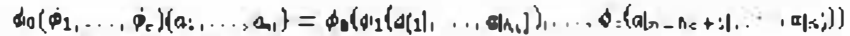

for all n-uplea $\left(a_{1}, \ldots, \theta_{n}\right)$

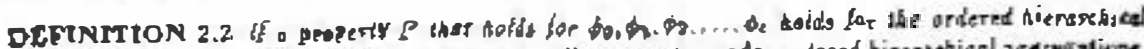

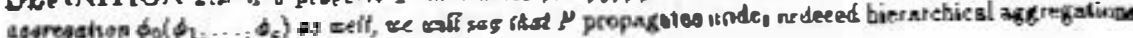

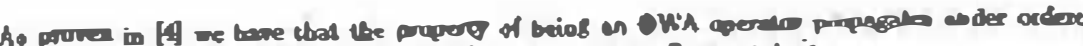

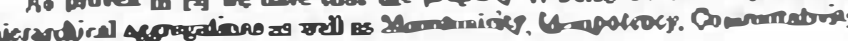

\section{On the degrees of Orness and Dispersion}

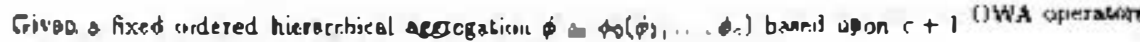
Yopro'z orbcos meanure tateo the r.xpression

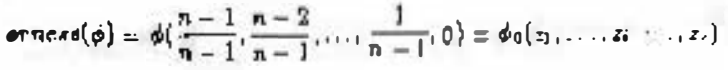

There

$$
\begin{aligned}
& 4=Q_{i}\left(-\frac{n-\left(\sum_{j=1}^{j-1} h_{j}+1\right)}{n-1}, \ldots+\frac{n-\sum_{-j=1}^{N} h_{2}}{n}\right)=
\end{aligned}
$$

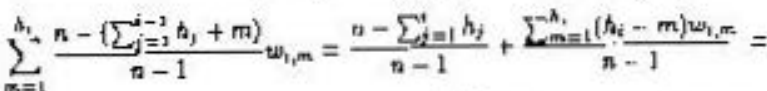

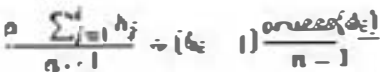

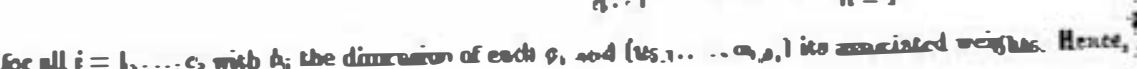

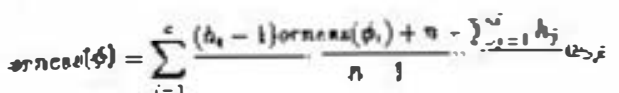

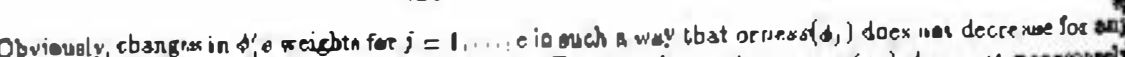

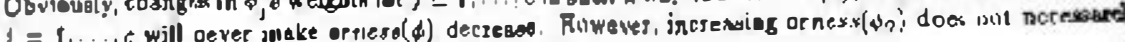

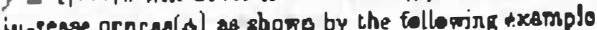

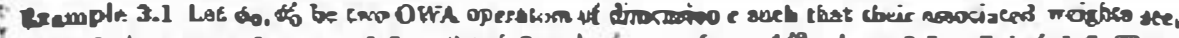

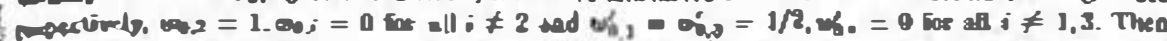

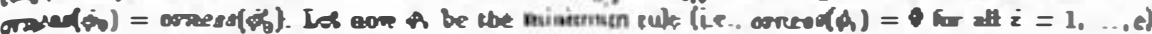

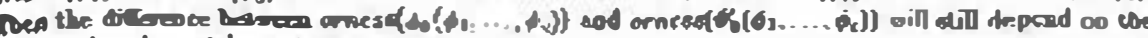

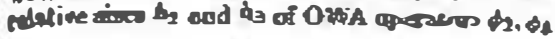

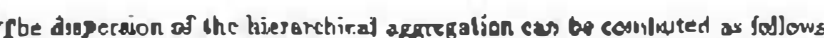

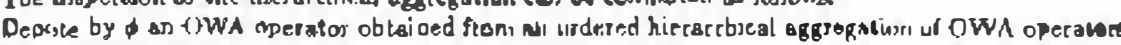
\$0,

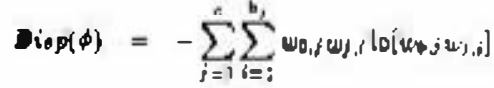

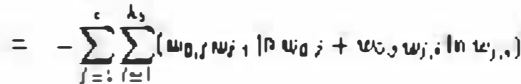

$$
\begin{aligned}
& =-\sum_{j=6}^{j}\left\{\tau_{0} \ln \omega_{n_{1} j}-\sum_{j=1}^{6} u_{v j} \operatorname{Dixp}\left(\phi_{j}\right)\right.
\end{aligned}
$$

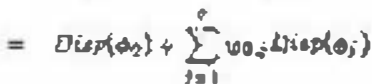

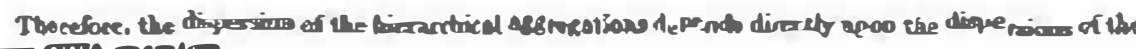
pinan OTA aperalor

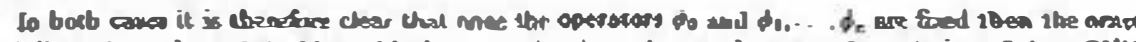

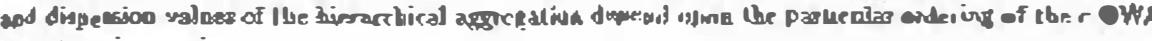
perstor go..... by

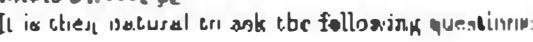

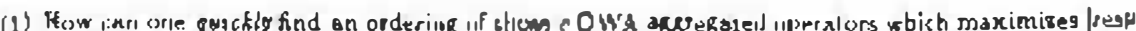

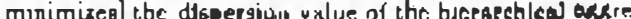

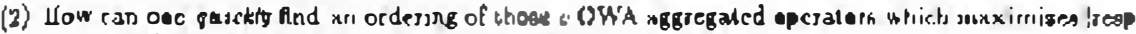

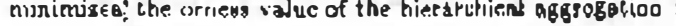

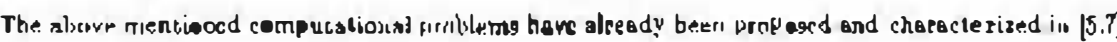

\section{Maximizing and minimizing dispersion and orness}

Let do be an OWA operator of dimengion 4 and lat - $\left\{a_{1} 1<<_{2} \leq c\right\}$ be a given ypt of OWA nperacors nad let $h_{1} . . .$. he lbeir rcspective dimenaisura

\subsection{Dispersion}

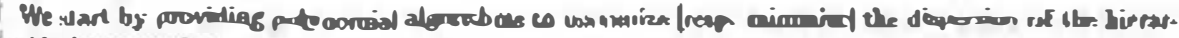
dical aggregation.

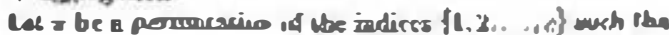

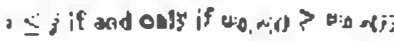

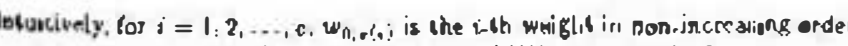

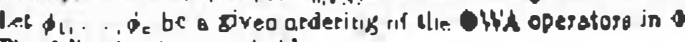

The following Jeomosnos bold 


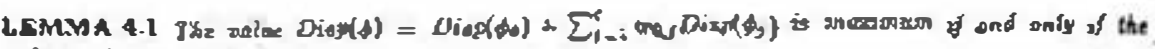
osderang An... . ar oovies

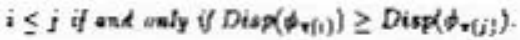

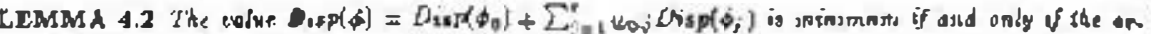
dering $\phi_{1}, \ldots$... di verofies

$$
i \leq j \text { s ond ondy } \sqrt{ } \text { Ois } x\left(\phi_{n}(i)\right) \leq D i s x(d-i j)
$$

In view uf the above Lemmas and frord tho well-kriwn result (see, o g . (1]) that. nry given n numberie

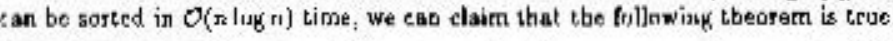

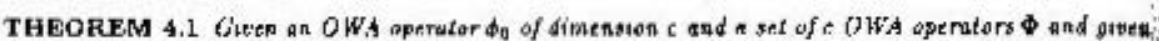

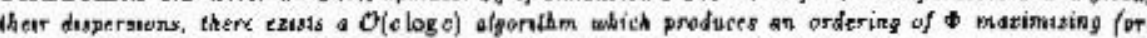
minsmitiog) the darpersion of the hierarchicel aggnegation.

\subsection{Orness}

The problem of mexiumsing of munimizing the orows of the hicrarchocal nggregation at a first aighi appease in be quile more diffeult from a conpulational point of sock sod ila (polyticmial) eolatios

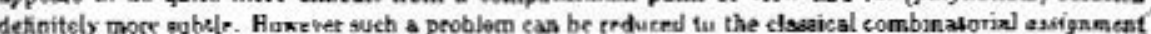

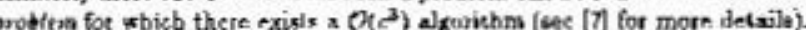

Briefly, lye liave thas

- denntert wilh d $\phi_{1}+\ldots . .0$, sbe OWA operaturx in 4 , and

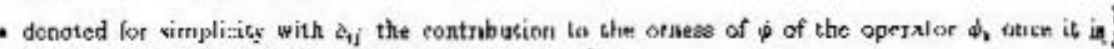

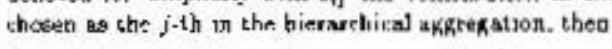

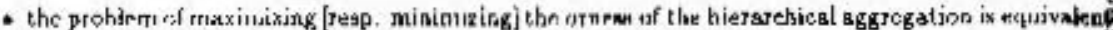
to the probirni of finding a perrmulationt of the rowa of the madrix

$$
M=\left(\begin{array}{cccc}
\delta_{21} & \delta_{12} & \ldots & \delta_{1 n} \\
\delta_{21} & \delta_{22} & \ldots & \delta_{2 c} \\
\vdots & \vdots & \ddots & \vdots \\
\hbar_{f 1} & \delta_{c z} & \ldots & \delta_{n s}
\end{array}\right)
$$

euch :hat the xym or I lar pletuests of the main daagonal if

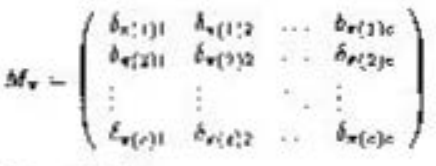

is mannum jesp mitumumi-i.e. soeh thet

$$
\sum_{i=1}^{\infty} \delta_{n i}
$$

ik zrıxirnum [reys:. nunimum].
The sb

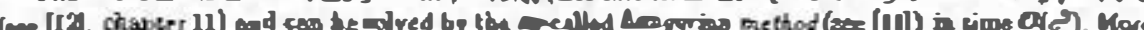
(wee

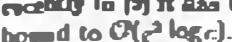

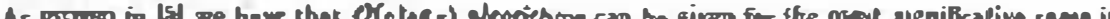
into cullo one index is is eammen to define them lo auth a way that cutber

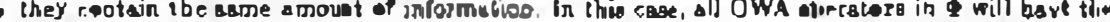
name dimeneivo to ourh that $n=$ hsior

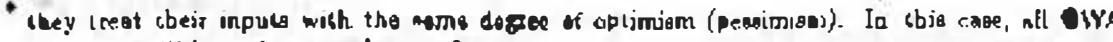

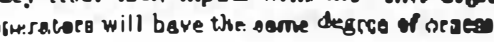

\section{Final Comments}

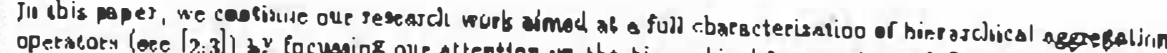

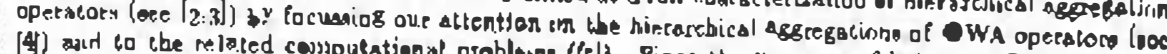

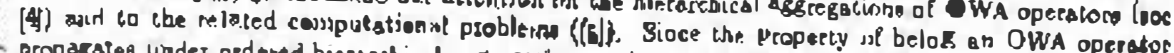

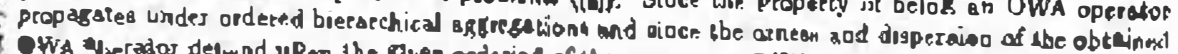

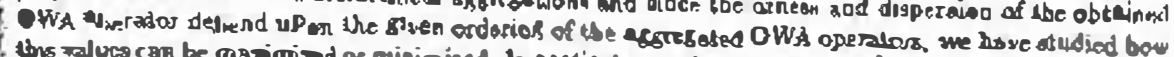

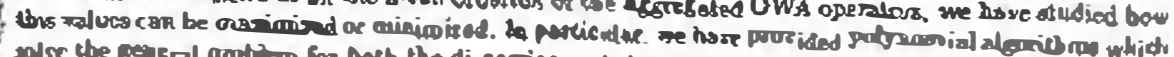

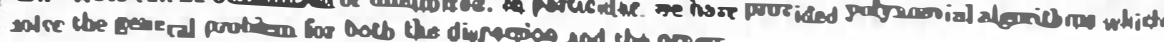

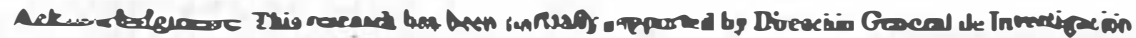

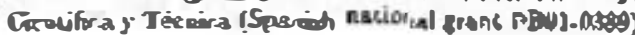

\section{References}

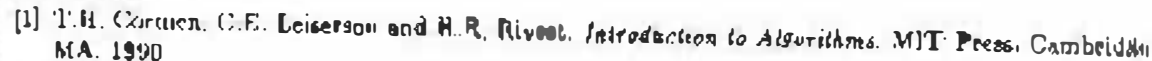
BCA. 1990

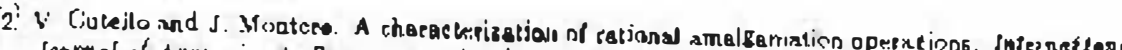
Journad nf Apptorimale Reasoging, vol. \& (A), PD. 32,5-344. June 1903.

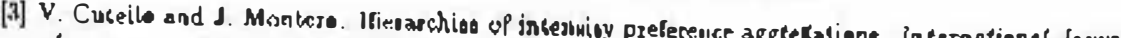
of Approjamate Reasering, vol. $10.123 .18 y, 1994$.

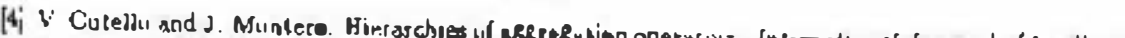
Systems, 9.1025.3045: 1994.

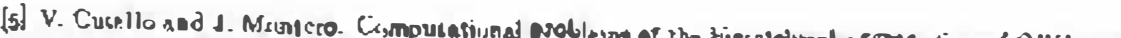

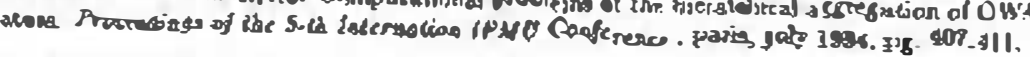

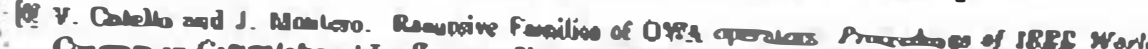

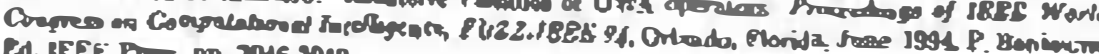
Co. IEEE PN-... Pp. Zo46-2040

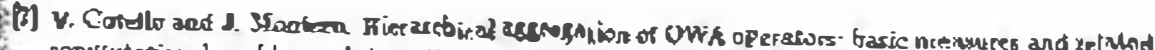

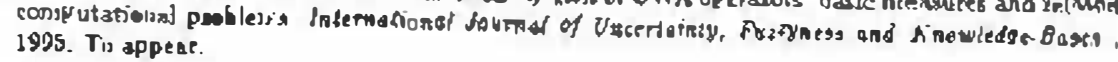

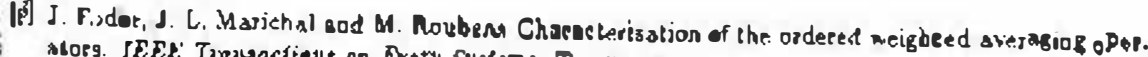

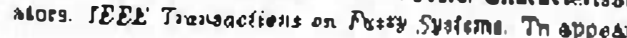


[9] M. L. Frodinan and R.E. Tiarjan. Fibenseci leenpe ond their wes in improved neetwurk optimizatiom

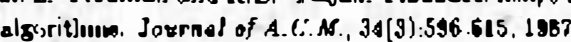

[10] G.J. Klir and T.A. Folzer. Fuzzy sets, ur.cervainfy ond infurmation Precritice Hall, Eaglewood Clifta NJ, 1988

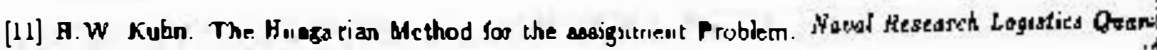
terty, 2:89-87, 1856.

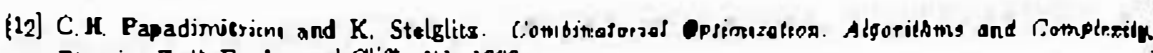
Ptentice He It. Engleneod Cliffo, Nd, 18y2

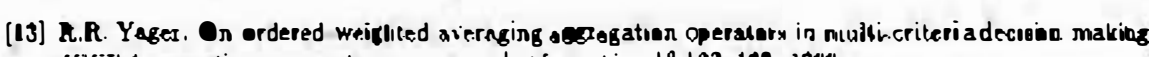

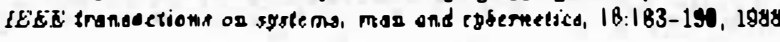

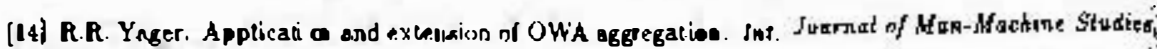
37:103-132.1992.
N GROUP DECISION MAKING UNDER LINGUISTIC PREFERENCES AND

\section{FUZZY LINGIISTIC QUANTIFIERS}

\section{Francieco HeRRERA, J.Luja VERDEgaV}

\author{
Dept. nf Campuher Stiences and Altificial Iotelligsene \\ Vavereit it os Graosda \\ 19071 - Granada, Spojin
}

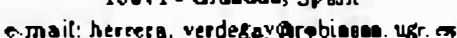

\section{ABSTRACT}

fin this paper some reaults on grenp deci sion makjes under linguigtic preferences and fuzzy ignigtic quastifiess afe presented. Assurning a set of individual linguistic prefereaces, rep rienting the preferences of the partic. ulas individuals, we develup a solution inethod for the ioich process. We define a linguistir. ondered weighted averaging operator, and uoe it for de Fing a cullective linguistic preference where the weights are defined using a fuzzy linguistic unitifier. Finally, we use the concept of nondoniryated alterinatives for ubtaning a set of max.

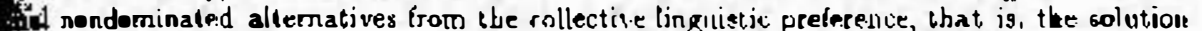
Fi the decision proces.

Covwords: Group deciaion making, linguistic preferences, tinguistjc auantifiers.

Introduction

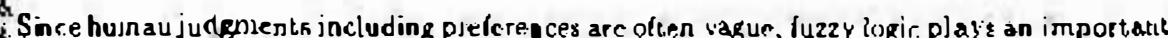
le in decision making Several authers have pmvided interesting results ou group decision thla corided a sorere flexibie fransewnek for diacussion group dccisjon suaking $[15,8,9,11]$.

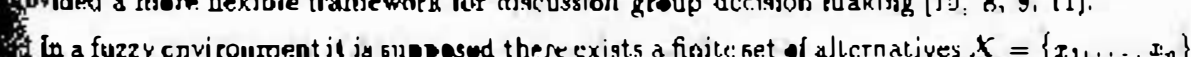
in wetl as a finite set of individuals $N=\{1, \ldots, m\}$, auck farb mdividual $k \in N$ providea bi:

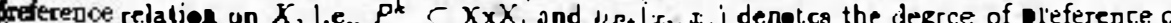
terative $x_{1}$ over $I_{j}, \mu_{r a}\left(x_{i}, x_{j}\right) \in[0, i]$

Sornetimes, however, an indjvidual wuld hale a vague information a boul the preference atree of the alternative $I_{i}$ over $I_{\text {, }}$ and can not estimale his preferel) ce: with ae exar.t oumeric

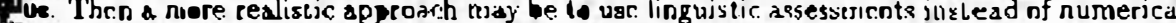
Thes, that is, 10 suppose that the variables (preferencu: relations: which participate in the Tablen are assegsed by meavg of biuguistic cerms 15,17 . 2, 4, 6. 12, A sc ale of cert aint

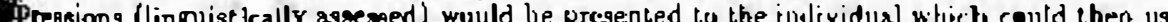
to deccribe his degree of certainty in a prefesence.

Asbuning a set of iudividual lingulstir nrefen:nces, we prosent a solictivu rncthod for the: ace proress. We define a collective linguistic ordered weighted aleraging $\{L O W A\}$ eperalor ase it for deriving a collective linguistir. pre:fcrence wibret the weights asr. defined uajing a 3y linguistic quantifier. Fiually, we use de amcept of uendomituated altetnatives for obtaning set of nlaximal nondominated alternalives frum the collortive linguistic preference. that is solation th the ircrision process.

This model seems to be more humau angsistent with thr: ancial choice in an imprecise froament. The linguiatic decision process can be aumnsusized in the tigure 1 


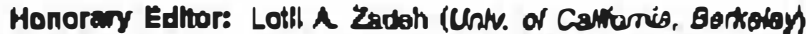

Eartas Edirors: Kaons Hirole (Tokyo inst of Tean).

Geang 1. Nir (SUNY at E!ngnention).

Elo Sanctior (Nramides.

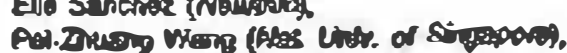

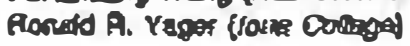

Vol. 1: Belween Mind and Compiter. Fuzzy 8cience ard Engheering (Eds. P.Z. Wang and K. F. LOE)

Voll 3: Comparaltuo Apploeches 10 l.dedicel Reaconing

(Eds. M. E. Cossor. and D. L. Hivedsers)

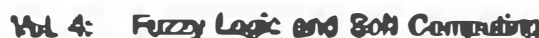

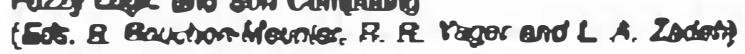

Forthcorring volumas:

Vol. 2: lindusurlal Appilogtlouts of Fuzzy Technology in the World Eds. $K$ Hirota and $M$. Sugenol

Vol. 5: Fuzzy 8etk, Fuzzy Logle, Applicalions

G Bojodizor ond M. Bojortions

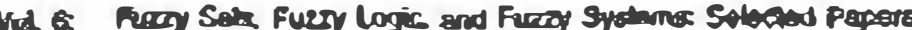
by Lott a $220 \mathrm{con}$

oy lout a 2200 n

VoL 7: Genotle Algcrithms and Fuzzy Logic Systems: Soll Cemputing Porgpectives

(Eds. E. Sanchoz, T. Shibeta and L a zodoh)

Editors

\section{Bernadette Bouchon-Meunier}

LAOORIA-18P, CNAS, Universing Pan's VI

\section{Ronald R. Yager}

rono cripge

Lotfi A. Zadeh

University of Castfornia. Gerketey
FUZZY LOGIC AND

SOFT COMPUTING 


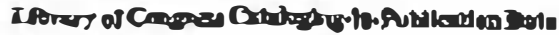

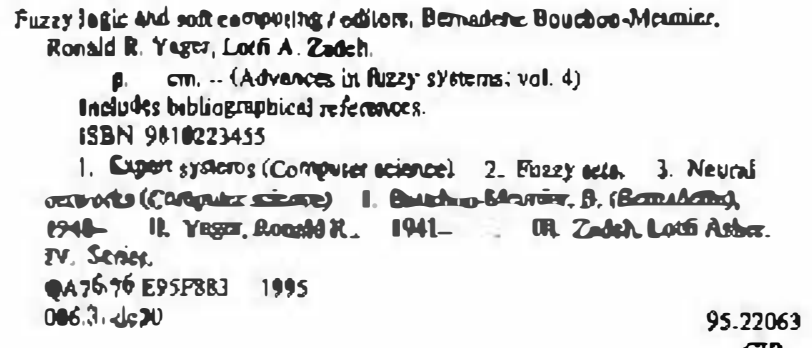

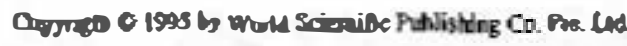

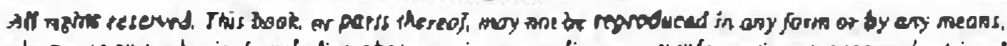

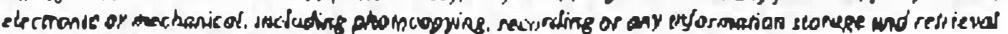

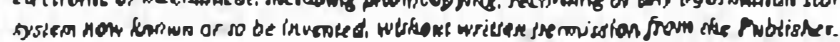

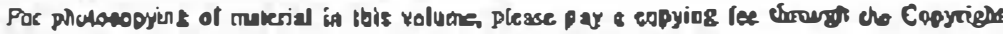

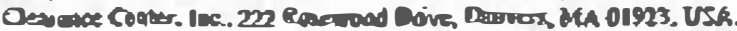

Sor computing constifutes a collection of disciplines which include fuzzy logic, neural

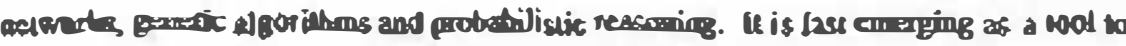
help computer-baced intelligent sy-stems mimic the ability of the human mind to employ modes of reasoning that are approximate rather than exact. The basic thesis of soft colpputing is that prectsion and cersinty carry a cost and Ihal intelligent systems should exploit. wherever possible. the tolerance for imprecision and uncerainty. Considurable worecs has been ashicued in the application of chis prociple. experialy with the use of fuary logic, in one developraem as a large nusnber of iniclligen conlral systems. These types of systems have appeared in applicotions as diver sc as layge scalc subway conlsuller; and as small as video cameras. We are now at a juucture where the ideas implieit in soft computing w: Il begis to have significant impact in many other doma ns of applicetion, this

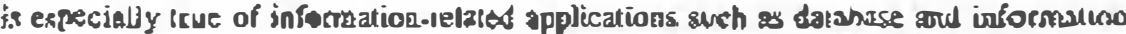

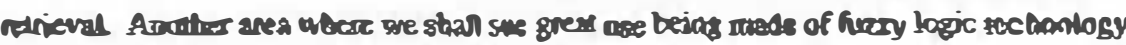
is in the construetion of "ehings that mink", for example a coat that car adapt us therrslal properties to different weather condisions.

This volume focuses on the cullent stale of soft computing, cspecialty the fuczy logic component. It comprises seven seetions. The fiest sectivn corsists of atree wricles

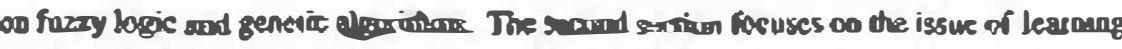
in son compatiog. The thizd section, on hybrid and fuzzy systentr, concerns jusclf with the use of firzy logic in a number of different paradignis employed in soft cumpuring. The laveth section is devored to decision and aggregation techrlques. The fifth section cencentrates on the Use of firz.y rechwologies in database syatems. The sixth section has

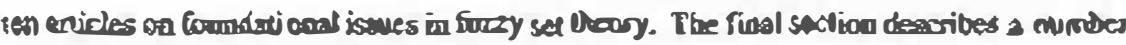
of spplicatians in whicb fuery logic plays a major mole.

B. Bouchon-Meuniee

R. R. Yager

L. A. Sadeh 